\title{
諸種氣体腹腔內送入の腸管吸收に及吉影響
}

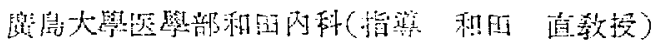

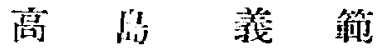

\section{INTESTINAL ABSORPTION INFLUENCED BY INTRAPERITONEAL PUMPING USING DIFFERENT GASES \\ Yoshinori Takashima}

Department of Internal Medicine, Hiroshima University Sunao School of Medicine

(Director: Prof. Sunao Wada)

The author has made a study of the influence produced in the intestinal absorption rate of pulmonary tuberculous patients and rabbits by pumping gases intraperito:leally using such gases as oxygen, carbon dioxide and nitrogen. The results observed are as follows :

(1) The intestinal absorption rate was definitely increased by short term normopressure pneumoperitoneum using oxygen with each subsequent intraperitoneal pumping. After reaching a maximun value at the 6 at 7 tin pumping, the intestinal absorption rate decreased gradually. The rate decreased more and more after transient high-pressure pneumoperitoneum, but it showed higher values than those before the first pneumoperitoneum.

(2) The rate showed a tendency to decrease with each subsequent pumping in cases of short term normopressure pneumoperitoneum using carbon dioxide.

(3) Tne fluctuation of the rate using nitrogen was almost the same as that using carbon dioxide. However, tendency later showed more rapid decrease.

(4) The intestinal absorption rate in all the groups of gases was less than that of prepumping mean value when the normo-and highpressure pneumoperitoneum was established for a long time. This was especially remarkable in the nitrogen group.

\section{緒 言}

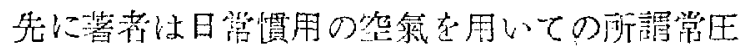

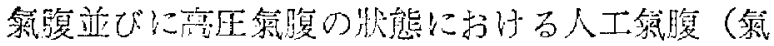

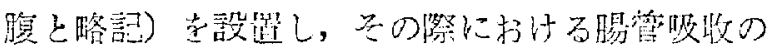

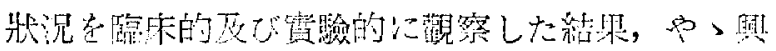

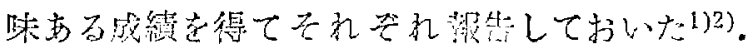

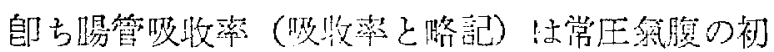

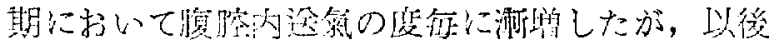

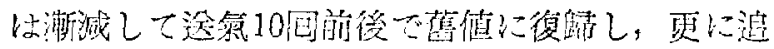

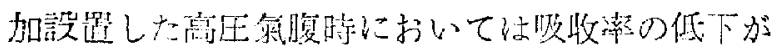

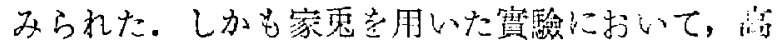

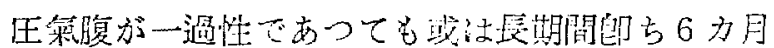

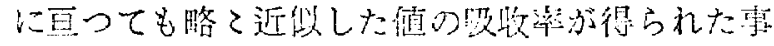
を証明した。

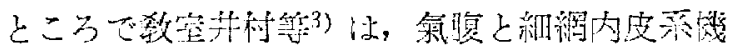

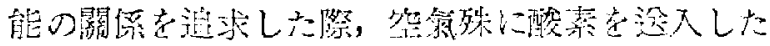

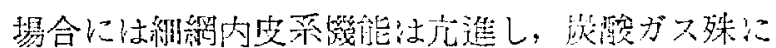

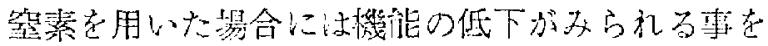

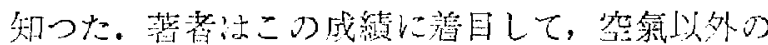

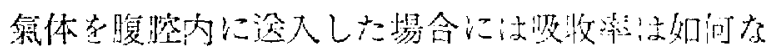




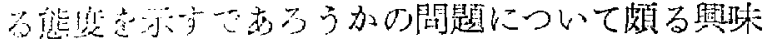

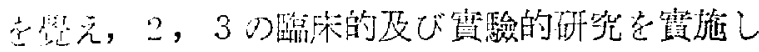

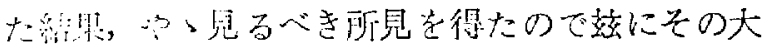

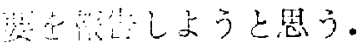

\section{赛驗方法}

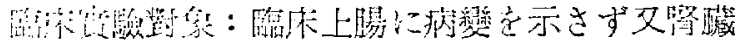

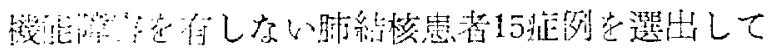

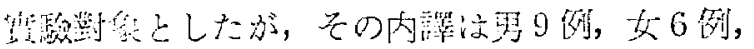
Minimal lesion

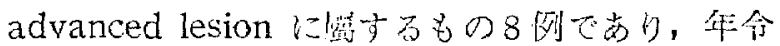

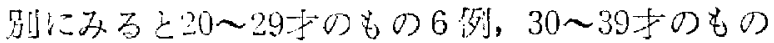

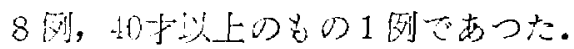

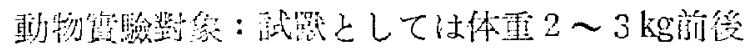

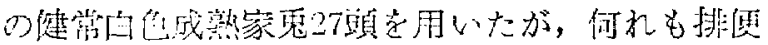

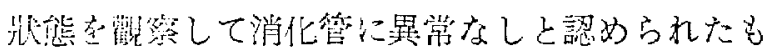
D本湿九枟。

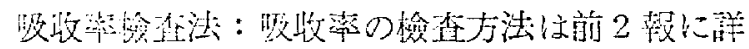

述しておいたので，重椱を渻ける。

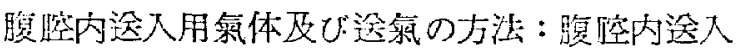

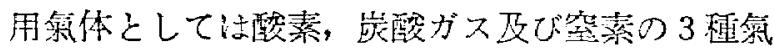

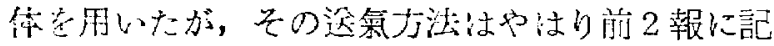

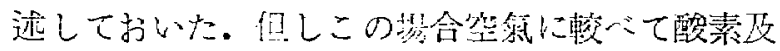

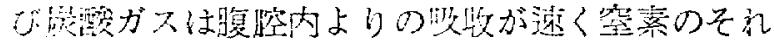

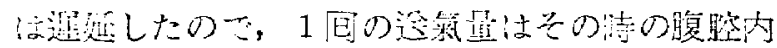

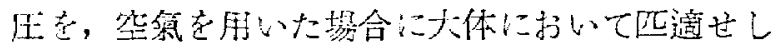

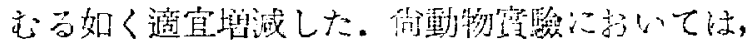

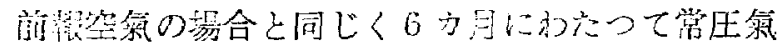

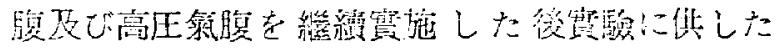

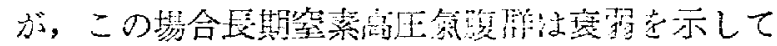

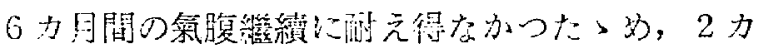

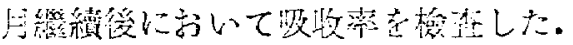

\section{臨汰實踰成瀆}

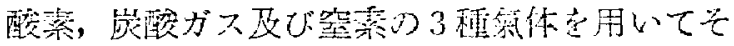

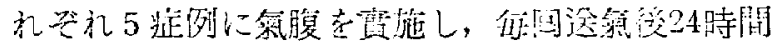

Table 1. Percentage of Intestinal Absorption in Cases treated with Pneumoperitoneum using Oxygen (Case 1).

\begin{tabular}{|c|c|c|c|c|c|c|c|c|c|c|}
\hline \multirow{3}{*}{$\begin{array}{l}\text { No. of } \\
\text { Refill- } \\
\text { ing }\end{array}$} & \multirow{3}{*}{\multicolumn{2}{|c|}{$\begin{array}{c}\text { Intraab- } \\
\text { dominal } \\
\text { Pressure } \\
\left(\mathrm{cm} \mathrm{H} \mathrm{H}_{2} \mathrm{O}\right)\end{array}$}} & \multicolumn{2}{|c|}{$\begin{array}{c}\text { Percentage } \\
\text { Administration } \\
\end{array}$} & \multicolumn{5}{|c|}{ Peroral Administration } & \multirow{3}{*}{$\begin{array}{l}\text { Percen- } \\
\text { tage of } \\
\text { Absorp- } \\
\text { tion } \\
(a b)\end{array}$} \\
\hline & & & \multirow{2}{*}{$\begin{array}{c}\text { Total } \\
\text { Amount } \\
\text { Excreted } \\
\text { into Urine } \\
(\mathrm{mg})\end{array}$} & \multirow{2}{*}{$\begin{array}{l}\text { Percenta- } \\
\text { ge of To- } \\
\text { tal Amo- } \\
\text { unt Excr- } \\
\text { eted }(\%)\end{array}$} & \multicolumn{3}{|c|}{$\begin{array}{l}\text { Percentoge of } \\
\text { Hourly Excretion }\end{array}$} & \multirow{2}{*}{$\begin{array}{c}\text { Total } \\
\text { Amount } \\
\text { Excreted } \\
\text { into Urine } \\
\text { (mg) }\end{array}$} & \multirow{2}{*}{$\begin{array}{l}\text { Yercenta- } \\
\text { ge of To } \\
\text { tal Amo- } \\
\text { unt Excr- } \\
\text { ated }(05)\end{array}$} & \\
\hline & & & & & $0-4$ & $4-12$ & $10-24$ & & & \\
\hline $\begin{array}{l}\text { Before } \\
\text { PP. }\end{array}$ & 1) & & 4.60 & 76.76 & 17.85 & 3.84 & 0 & 12.34 & 24.69 & 3.16 \\
\hline 1 & $\begin{array}{r}u \\
+4 \\
\end{array}$ & -+5 & 3.94 & 65.78 & 15.60 & 9.80 & 0 & 12.70 & 35.40 & 38.131 \\
\hline$\because$ & $\begin{array}{r}0 \\
+3 \\
\end{array}$ & -+4 & 4.34 & 72.46 & 10.41 & 16.66 & 0 & 13.53 & $\therefore 7.07$ & 37.22 \\
\hline 3 & $\begin{array}{r}0 \\
+5\end{array}$ & -+6 & 4.28 & 71.42 & 6.57 & 17.85 & 4.90 & 14.16 & 28.63 & 39.66 \\
\hline 4 & $\begin{array}{r}0 \\
+5 \\
\end{array}$ & -+6 & 4.05 & 67.56 & 7.45 & 18.86 & 1.96 & 13.29 & $\because 0.58$ & 30.84 \\
\hline 5 & $\begin{array}{r}0 \\
+f i \\
\end{array}$ & -+8 & 4.22 & 70.43 & 14.49 & 18.69 & 0 & 14.09 & 29.18 & 40.01 \\
\hline 6 & $\begin{array}{r}15 \\
+8 \\
\end{array}$ & -+4 & 4.41 & 73.52 & 7.80 & 19.60 & 2.63 & $15.0 \mathrm{I}$ & 30.03 & 40.84 \\
\hline$T$ & $\begin{array}{r}0 \\
+5 \\
\end{array}$ & -+6 & 4.10 & 68.49 & 12.21 & 14.49 & 3.12 & 14.72 & 29.80 & 48.58 \\
\hline 8 & $\begin{array}{r}0 \\
+5 \\
\end{array}$ & $-+i$ & 4.16 & 69.44 & 6.06 & 17.54 & 5.20 & $11 .+1$ & 28.88 & +1.51 \\
\hline$y$ & $\begin{array}{l}+3 \\
+5 \\
\end{array}$ & $\begin{array}{l}-+3.5 \\
-+6 \\
\end{array}$ & 4.47 & $7 \pm .62$ & 7.35 & 19.23 & 3.80 & $1 \overline{5} .10$ & $: 311.28$ & 40.71 \\
\hline 10 & $\begin{array}{r}0 \\
+5 \\
\end{array}$ & -+7 & 4.15 & 69.20 & $7.5 \%$ & 18.51 & 3.20 & 14.61 .4 & 29.28 & 42.31 \\
\hline HP.PP. & $\begin{array}{l}+2 \\
+18 \\
\end{array}$ & $\begin{array}{l}-+3 \\
-+90 \\
\end{array}$ & 3.89 & 64.93 & 19.19 & 12.65 & 0 & 12.42 & 24.81 & 85.25 \\
\hline
\end{tabular}

Note: HP. PP.: Highpressure Pneumoperitoneum 
にして吸收家を检㭗した結果, 各 5 症例は各群ご とにそれ次れ大体において類似した傾向を示した ので，記述の㥧定避けるため各群各１例を例に上 つて表示記述する邫とした。

\section{酸素氮腹 :}

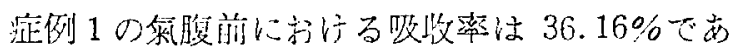
ったがこえれに對して透氮 1 国㣭のそれは 38.61

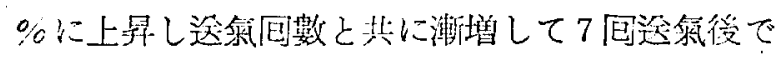
は 43.58\%となつて最高値を示し，その後も變化 は棗度で10尼邆姚後には 42.31\%であつた。引縞 さ一過性高压氣腹き試みたところ, 吸收率は稍て 低下して $38.25 \%$ となつたが氣䠦前値に較べると なお明ら加高梴老維持した（Table 1).

炭酸ガス氣腹:

氮腹前 $33.21 \%$ でつた症例 6 の吸收率は䢒氣 各包を通じて殆ど類似心值を示した。毁ち最低値 は2 尼送氯後の $30.97 \%$ ，最高值は 8 回总氮後の
34.09\%で，吸收率の差は嚾少に止まつた。こ れに一過性高王氧腹を行なつた所，その吸收率は 30.95\%となつて上記常区氣腹中に得られた敘値 と数伿しており，その影響は輕微であつた (Table 2).

\section{空素策腹 :}

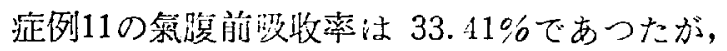

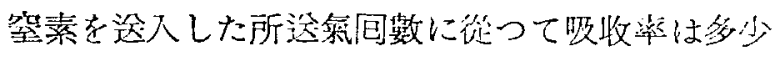
漸減の偭向齐示し，8回逘氣後において注 24.82 \%となつた。次いて，一過性高王氣腹を試みたと ころ，吸收率注著減して $22.38 \%$ という値を示し た (Table 3 ).

\section{小括:}

以上 3 種氮体を用いて常王氣腹及び一過性高压 埭腹を行なつた徭における吸收深の推移を, 臨床 的に觀察した成續を記述したが，今墄みに上述 3 群と前司に報告した筀氣氣腹群の平均値をそれぞ

Table 2. Percentage of Intestinal Absorption in Cases

treated with Pneumoperitoneum using Carbon Dioxide(Case 6).

\begin{tabular}{|c|c|c|c|c|c|c|c|c|c|}
\hline \multirow{3}{*}{$\begin{array}{l}\text { No. of } \\
\text { Refill- } \\
\text { ing }\end{array}$} & \multirow{3}{*}{$\begin{array}{l}\text { Intrab- } \\
\text { dominal } \\
\text { Pressure } \\
\left(\mathrm{cm} \mathrm{H}_{2} \mathrm{O}\right)\end{array}$} & \multicolumn{2}{|c|}{$\begin{array}{c}\text { Percentage } \\
\text { Administration }\end{array}$} & \multicolumn{5}{|c|}{ Peroral Administration } & \multirow{3}{*}{$\begin{array}{l}\text { Percen- } \\
\text { tage of } \\
\text { Absorp- } \\
\text { tion } \\
(0,0)\end{array}$} \\
\hline & & \multirow{2}{*}{$\begin{array}{c}\text { Total } \\
\text { Amount } \\
\text { Excreted } \\
\text { into Urine } \\
\text { (mg) }\end{array}$} & \multirow{2}{*}{ 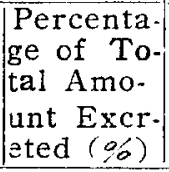 } & \multicolumn{3}{|c|}{$\begin{array}{l}\text { Percentage of } \\
\text { Hourly Excretion }\end{array}$} & \multirow{2}{*}{$\begin{array}{c}\text { Cotal } \\
\text { Amount } \\
\text { Excreted } \\
\text { into Urine } \\
\text { (mg) }\end{array}$} & \multirow{2}{*}{$\begin{array}{l}\text { Percenta- } \\
\text { ge of To } \\
\text { tal Amo- } \\
\text { unt Excr- } \\
\text { zted }(0,6)\end{array}$} & \\
\hline & & & & $0-4$ & $4-12$ & $12-24$ & & & \\
\hline $\begin{array}{c}\text { Before } \\
\text { PP. }\end{array}$ & 0 & 3.89 & 64.93 & 10.10 & 11.49 & 0 & 10.79 & 21.59 & 33.25 \\
\hline 1 & $\begin{array}{r}0 \\
+3-+4 \\
\end{array}$ & 4.41 & 73.54 & 6.41 & 16.39 & 2.00 & 12.40 & 24.80 & 33.73 \\
\hline 2 & $\begin{array}{r}0 \\
+4-+5 \\
\end{array}$ & 4.22 & 70.42 & 18.29 & 7.46 & 0 & 15.45 & 25.75 & 36.56 \\
\hline 3 & $\begin{array}{r}0 \\
+8-+9 \\
\end{array}$ & 4.23 & 70.57 & 11.62 & 13.15 & 0 & 12.38 & 24.77 & 35.09 \\
\hline 4 & $\begin{array}{r}0 \\
+8-8-9 \\
\end{array}$ & 4.32 & 72.13 & 11.76 & 9.25 & 2.55 & 11 & 23.50 & 32.66 \\
\hline 5 & $\begin{array}{r}0 \\
+9-+10 \\
\end{array}$ & 4.47 & 74.62 & 11.49 & 12.04 & 0 & 11.76 & 23.53 & 31.53 \\
\hline 6 & $\begin{array}{l}+2-+3 \\
+8-+9 \\
\end{array}$ & 4.05 & 67.56 & 12.34 & 9.80 & 0 & 11.07 & 22.14 & 32.77 \\
\hline 7 & $\begin{array}{r}0 \\
+8-+9\end{array}$ & 4.54 & 75.75 & 9.61 & 17.54 & 0 & 16.20 & 27.15 & 35.84 \\
\hline 8 & $\begin{array}{l}+2-13 \\
+9-+10 \\
\end{array}$ & 4.68 & 78.01 & 8.62 & 16.94 & 1.23 & 16.07 & 26.79 & 34.34 \\
\hline 9 & $\begin{array}{r}0 \\
+7-8 \\
\end{array}$ & 4.16 & 69.44 & 5.88 & 14.49 & 0 & 10.18 & $20.3 \pi$ & 29.83 \\
\hline 10 & $\begin{array}{r}0 \\
+7-+8 \\
\end{array}$ & 4.23 & 70.64 & 10.41 & 13.15 & 0 & 11.78 & 23.56 & 83.35 \\
\hline HP.PP. & $\begin{array}{c}0 \\
+16-+18 \\
\end{array}$ & 4.34 & 78.46 & 11.23 & 11.76 & 0 & 11.49 & 22.99 & 31.72 \\
\hline
\end{tabular}

Note: Same as Table 1 
Table 3. Percentage of Intestinal Absorption in Cases treated with Pneumoperitoneum using Nitrogen. (Case 11)

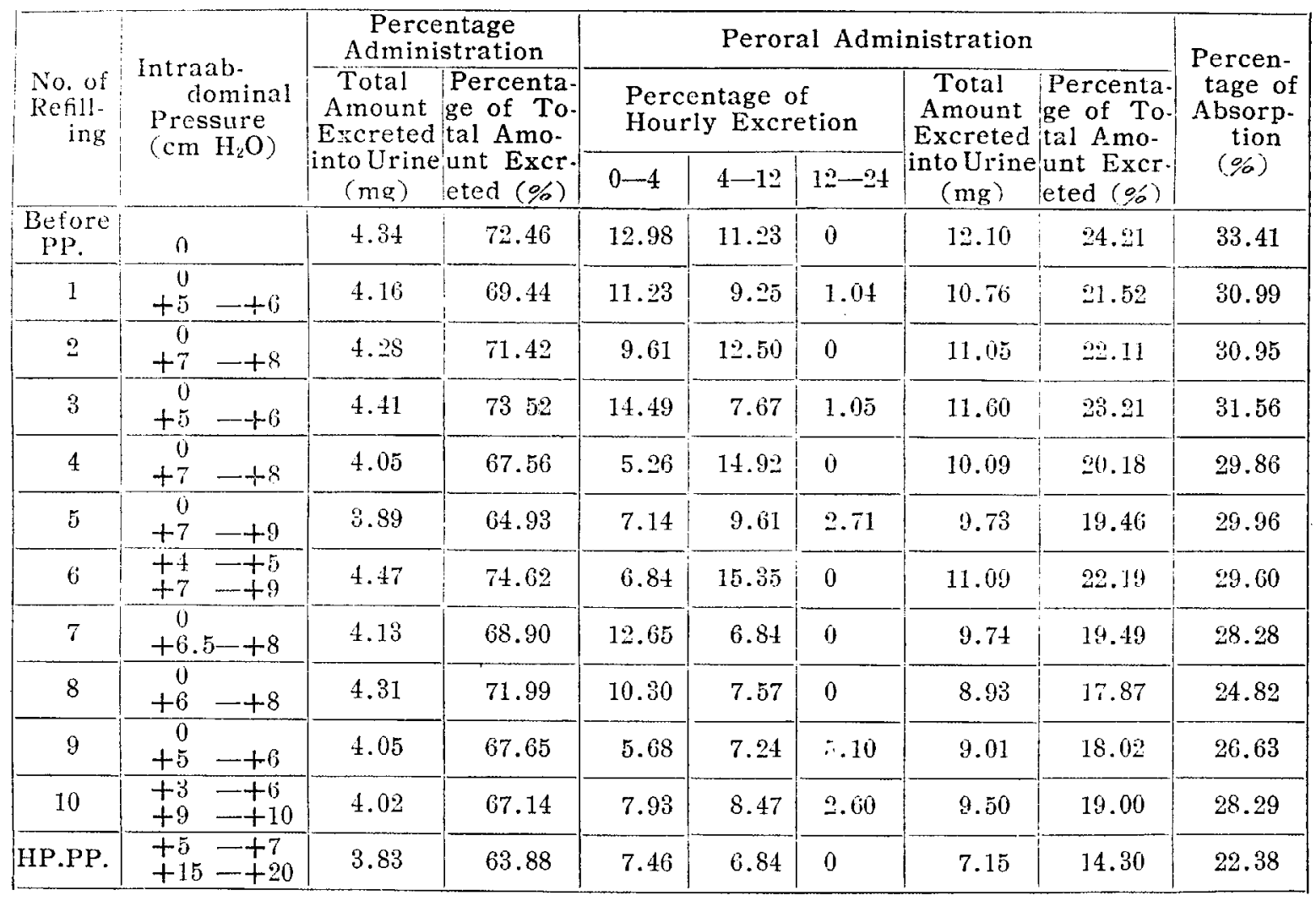

Note: Same as Table 1

Fig. 1. Fluctuation of Mean Values of Intestinal Absorption Percentage seen in cases treated with Pneumoperitoneum using 4 Different Gases.

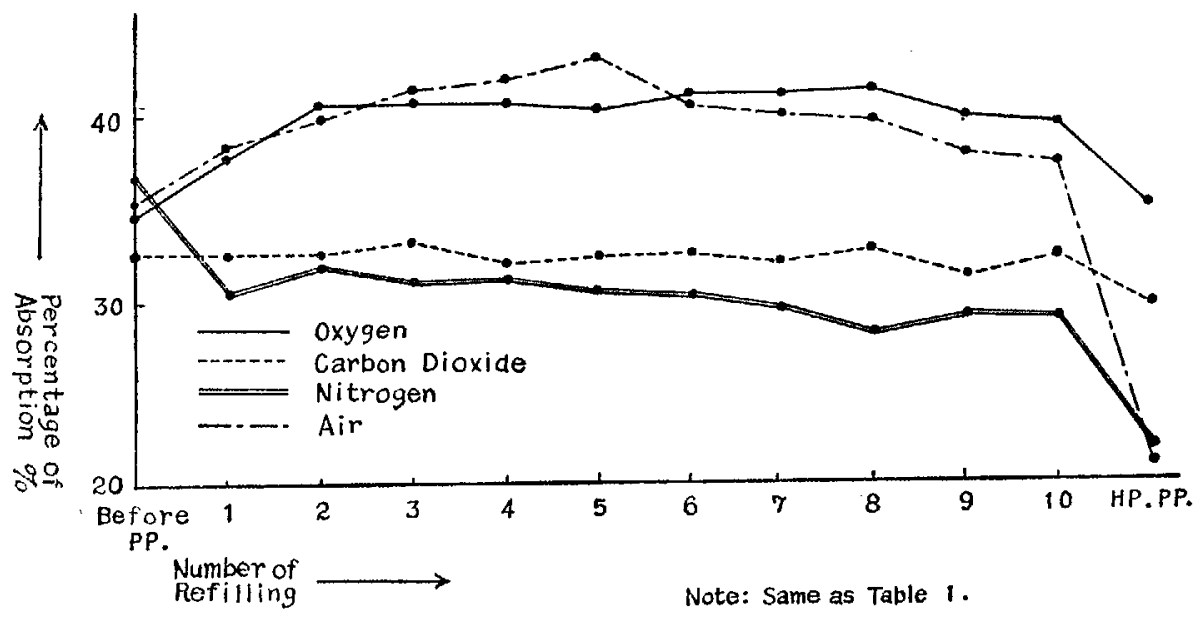

れ求めて此較温示すると Fig. 1 の㚼くである.ま

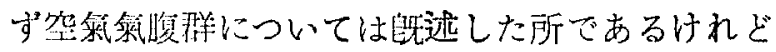

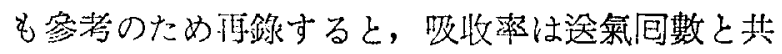

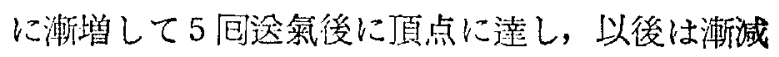
して10回䢒氮後には氮腹前値に近接した。次いで 一過性高压氯腹を行うと吸收率は激減して 21.72 


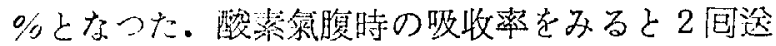

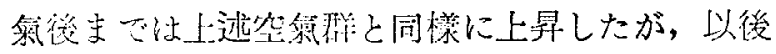
8 目运筑後主では一定万至はや>堌加の傾向を， 9 更び10四䢒氮後ではや>低下の傾向を示した。

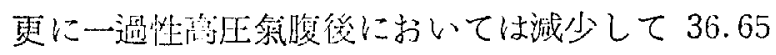

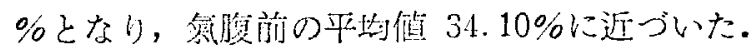

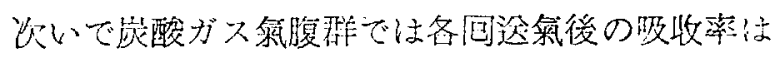

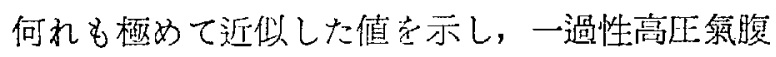
後においても輕微な低下が認められるに過ぎなか つた。咥素氯腹群における吸收率は，大体におい て漸次下降を續ける傾向を示し，一過性高王氣腹 後には激減して $22.94 \%$ となつた。

以上の如く常正氣腹時における吸收率をみる と, 空氮埭腹群々酸素氭腹群とは類似した傾向を もつて推移しており，一方宸酸力又氣腹群と筑素 氮腹群とは又稍て似通つた推移を示した，何高圧 氣腹實拖後においてはいずれの群においても判然 と減少したが，空素葲腹群と空氯氣腹群において は特に顯著な低下がみられた。

\section{動物贯驗成樍}

I 短期常区氣腹及び一過性高圧氮腹時の胞管

\section{吸收率}

健常家雨 9 頭を 3 例宛 3 群に分け，これに酸

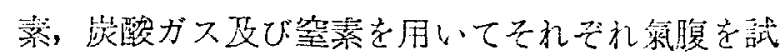

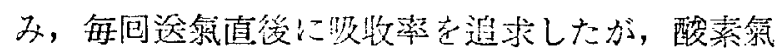

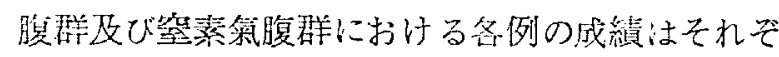
れ殆ど類似した傾问であつた〉め，前項と同樣各 群各 1 例の成績を表示し，且つ話明する事とした が，炭酸ガス氣腹群のそれは 3 例が方のうの多少 異なつており特にそれぞれの成績を記述した。

酸索氮腹 :

第 1 例の吸收率は氮腹前 $70.12 \%$ あのつたが，

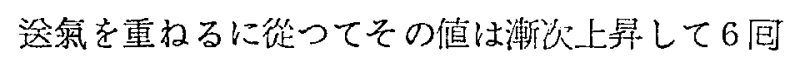
这氮後には最高値たる $83.45 \%$ を示し, 以後は輕 度に低下したとは言うもの>氮腹前に較べると椖 かに高率のま〉經過した。11回选氮時に一過性高 区氣腹を試みた所, 吸收率は減少して $71.49 \%$ と なつたがこれとても氮腹前值を下まわるもので はなかつた (Table 4).

炭酸ガス氣腹 :

既述の如く本實驗群の成續は他の群のそれに較 べるど制然と一定した傾问が認め難かつたので，

Table 4. Percentage of Intestinal Absorption in Rabbits treated with Pneumoperitoneum using Oxygen. (Rabbit No. 1).

\begin{tabular}{|c|c|c|c|c|c|c|c|c|}
\hline \multirow{3}{*}{$\begin{array}{l}\text { No. of } \\
\text { Refilling }\end{array}$} & \multicolumn{2}{|c|}{$\begin{array}{c}\text { Percentage } \\
\text { Administration }\end{array}$} & \multicolumn{5}{|c|}{ Peroral Administration } & \multirow{3}{*}{$\begin{array}{c}\text { Percentage } \\
\text { of } \\
\text { Absorption } \\
(00)\end{array}$} \\
\hline & \multirow{2}{*}{$\begin{array}{c}\text { Total } \\
\text { Amount } \\
\text { Excreted } \\
\text { into Urine } \\
\text { (mg) }\end{array}$} & \multirow{2}{*}{$\begin{array}{c}\text { Percentage } \\
\text { of Total } \\
\text { Amount } \\
\text { Excreted } \\
(\%)\end{array}$} & \multicolumn{3}{|c|}{$\begin{array}{l}\text { Percentage of } \\
\text { Hourly Excretion }\end{array}$} & \multirow{2}{*}{$\begin{array}{c}\text { Total } \\
\text { Amount } \\
\text { Excreted } \\
\text { into Urine } \\
\text { (mg) }\end{array}$} & \multirow{2}{*}{$\begin{array}{c}\text { Percentage } \\
\text { of Total } \\
\text { Amount } \\
\text { Excreted } \\
(\%)\end{array}$} & \\
\hline & & & $0-4$ & $4-12$ & $19-24$ & & & \\
\hline Before PP. & 3.57 & 71.42 & 0 & 15.60 & 34.48 & 5.00 & 50.08 & 70.12 \\
\hline 1 & 3.50 & 70.03 & 5.26 & 6.75 & 39.00 & 5.10 & 51.01 & $7 \therefore .84$ \\
\hline 2 & 3.20 & 64.10 & 5.95 & 9.80 & 32.25 & 4.80 & 48.00 & 74.88 \\
\hline 3 & 3.42 & 68.49 & 0 & 9.61 & 40.98 & 5.05 & 50.59 & 73.86 \\
\hline 4 & 3.23 & 64.75 & 0 & 0 & 52.07 & 5.20 & 52.07 & 80.41 \\
\hline 5 & 3.67 & 73.52 & 0 & 24.68 & 34.72 & 5.94 & 59.40 & 80.79 \\
\hline 6 & 3.47 & 69.44 & 0 & 30.48 & 27.47 & 5.79 & 57.95 & 83.45 \\
\hline 7 & 3.41 & 68.31 & 0 & 0 & 54.34 & 5.43 & 54.34 & 79.78 \\
\hline 8 & 3.16 & 63.29 & 0 & 21.42 & 26.88 & 4.83 & 48.30 & 76.31 \\
\hline 9 & 3.28 & 65.78 & 2.74 & 13.69 & 32.46 & 4.88 & 48.89 & 74.32 \\
\hline 10 & 3.64 & 72.87 & 0 & 6.84 & 49.99 & 5.68 & 56.83 & 79.36 \\
\hline HP. PP. & 3.17 & 63.57 & 0 & 0 & 45.45 & 4.54 & 45.45 & 71.49 \\
\hline
\end{tabular}

Note: Same as Table 1 
3 侧热沉ついて記戟しておきたい。

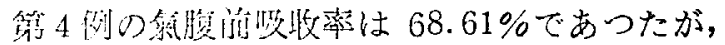

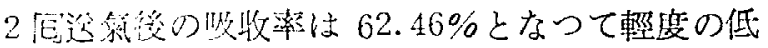

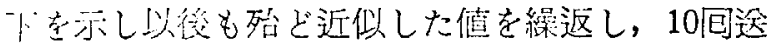

氯後で注 $64.63 \%$ であつた。次いで過性高圧氮 腹を行なつた後の吸收率は $60.75 \%$ と稍て低下が みられた。第 5 例について注第腹前侹 $63.78 \%$ に

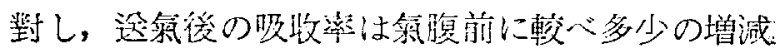

Table 5. Percentage of Intestinal Absorption in Rabbits treated with Pneumoperitoneum using Carbon Dioxide. (Rabbit No. 4)

\begin{tabular}{|c|c|c|c|c|c|c|c|c|}
\hline \multirow{3}{*}{$\begin{array}{l}\text { No. of } \\
\text { Refilling }\end{array}$} & \multicolumn{2}{|c|}{$\begin{array}{c}\text { Percentage } \\
\text { Administration }\end{array}$} & \multicolumn{5}{|c|}{ Peroral Administration } & \multirow{3}{*}{$\begin{array}{c}\text { Percentage } \\
\text { of } \\
\text { Absorption } \\
(\%)\end{array}$} \\
\hline & \multirow{2}{*}{$\begin{array}{c}\text { Total } \\
\text { Amount } \\
\text { Excreted } \\
\text { into Urine } \\
\text { (mg) }\end{array}$} & \multirow{2}{*}{$\begin{array}{c}\text { Percentage } \\
\text { of Total } \\
\text { Amount } \\
\text { Excreted } \\
(\%)\end{array}$} & \multicolumn{3}{|c|}{$\begin{array}{l}\text { Percentage of } \\
\text { Hourly Excretion }\end{array}$} & \multirow{2}{*}{$\begin{array}{c}\text { Total } \\
\text { Amount } \\
\text { Excreted } \\
\text { into Urine } \\
(\mathrm{mg})\end{array}$} & \multirow{2}{*}{$\begin{array}{c}\text { Percentage } \\
\text { of Total } \\
\text { Amount } \\
\text { Excreted } \\
(0,0)\end{array}$} & \\
\hline & & & $0-4$ & $4-12$ & $12-24$ & & & \\
\hline Before Pr. & 3.16 & 63.32 & 0 & 13.69 & 29.76 & 4.34 & 43.45 & 68.61 \\
\hline 1 & 3.06 & 61.34 & 0 & 11.23 & 30.86 & 4.20 & 42.09 & 68.61 \\
\hline 2 & 3.28 & 65.78 & 0 & 0 & 41.09 & 4.10 & 41.09 & 62.46 \\
\hline 8 & 3.40 & 68.18 & 0 & $\overline{5.10}$ & 37.03 & 4.21 & 42.13 & 61.79 \\
\hline 4 & 3.42 & 68.49 & 0 & 2.65 & 40.53 & 4.31 & 43.18 & 63.04 \\
\hline$\tilde{b}$ & 3.25 & 65.14 & 0 & 0 & 39.46 & 3.94 & 39.46 & 60.57 \\
\hline 6 & 3.13 & 62.67 & 0 & 6.49 & 33.78 & 4.02 & 40.27 & 64.25 \\
\hline 7 & 3.46 & 69.36 & 0 & 16.39 & 26.31 & 4.57 & 42.70 & 61.56 \\
\hline 8 & $\therefore .210$ & 64.10 & 0 & 0 & 42.85 & 4.28 & $4: 2.85$ & 66.84 \\
\hline 9 & 3.02 & 60.59 & 0 & 0 & 37.31 & 3.73 & 37.31 & 61.47 \\
\hline 10 & 3.08 & 61.79 & 2.68 & 7.14 & 30.12 & 3.99 & 39.94 & 64.63 \\
\hline HP. PP. & 3.02 & 60.51 & 0 & 0 & 39.76 & 3.67 & 36.76 & 60.75 \\
\hline
\end{tabular}

Note: Same as Table 1

Table 6 Percentage of Intestinal Absorption in Rabbits treated with Pneumoperitoneum using Carbon Dioxide. (Rabbit No. 5)

\begin{tabular}{|c|c|c|c|c|c|c|c|c|}
\hline \multirow{3}{*}{$\begin{array}{l}\text { No. of } \\
\text { Refilling }\end{array}$} & \multicolumn{2}{|c|}{$\begin{array}{c}\text { Percentage } \\
\text { Administration }\end{array}$} & \multicolumn{5}{|c|}{ Peroral Administration } & \multirow{3}{*}{$\begin{array}{l}\text { Percentage } \\
\text { of } \\
\text { Absorption } \\
(00)\end{array}$} \\
\hline & \multirow{2}{*}{$\begin{array}{c}\text { Total } \\
\text { Amount } \\
\text { Excreted } \\
\text { into urine } \\
\text { (mg) }\end{array}$} & \multirow{2}{*}{$\begin{array}{c}\text { Percentage } \\
\text { of Total } \\
\text { Amount } \\
\text { Excreted } \\
(\%)\end{array}$} & \multicolumn{3}{|c|}{$\begin{array}{l}\text { Percentage of } \\
\text { Hourly Excretion }\end{array}$} & \multirow{2}{*}{$\begin{array}{c}\text { Total } \\
\text { Amount } \\
\text { Excreted } \\
\text { into Urine } \\
\text { ( } \mathrm{mg})\end{array}$} & \multirow{2}{*}{$\begin{array}{c}\text { Percentage } \\
\text { of Total } \\
\text { Amount } \\
\text { Excreted } \\
(00)\end{array}$} & \\
\hline & & & $0-4$ & $4-12$ & $12-24$ & & & \\
\hline Before PP. & 3.28 & 65.78 & 0 & 7.24 & 34.72 & 4.19 & 11.96 & 63.78 \\
\hline 1 & 3.38 & 67.76 & 0 & 0 & 43.47 & 4.34 & 43.47 & 64.15 \\
\hline 2 & 3.04 & 60.91 & 0 & 9.80 & 26.88 & 3.66 & 36.68 & 60.21 \\
\hline 3 & 3.25 & 65.00 & 0 & 8.06 & 36.23 & 4.43 & 44.29 & 68.18 \\
\hline 4 & 3.34 & 66.81 & 5.31 & 8.92 & 26.59 & 4.08 & 40.82 & 61.09 \\
\hline 5 & 3.17 & 63.42 & 0 & 14.58 & 27.65 & 4.22 & 42.23 & 66.58 \\
\hline 6 & 3.36 & 67.33 & 0 & 0 & 40.98 & 4.09 & 49.98 & 60.86 \\
\hline 7 & 3.39 & 67.99 & 0 & 10.86 & 29.41 & 4.02 & 40.97 & 59.22 \\
\hline 8 & 3.25 & 65.04 & 0 & 6.94 & 35.21 & 4.21 & 49.15 & 64.80 \\
\hline 9 & 8.40 & 68.04 & 6.49 & 9.25 & 24.68 & 4.04 & 40.42 & 59.40 \\
\hline 10 & 3.64 & 72.87 & 4.38 & 5.74 & 31.25 & 4.13 & 41.37 & 56.77 \\
\hline HP. PP. & 3.31 & 66.21 & 0 & 12.82 & 25.51 & 3.88 & 38.33 & 57.90 \\
\hline
\end{tabular}

Note: Same as Table 1 
Table 7. Percentage of Intestinal Absorption in Rabbits treated with Pneumoperitoneum using Carbon Dioxide. (Rabbit No.6)

\begin{tabular}{|c|c|c|c|c|c|c|c|c|}
\hline \multirow{3}{*}{$\begin{array}{l}\text { No. of } \\
\text { Refilling }\end{array}$} & \multicolumn{2}{|c|}{$\begin{array}{c}\text { Percentage } \\
\text { Administration }\end{array}$} & \multicolumn{5}{|c|}{ Peroral Administration } & \multirow{3}{*}{$\begin{array}{c}\text { Percentage } \\
\text { of } \\
\text { Absorption } \\
(00)\end{array}$} \\
\hline & \multirow{2}{*}{$\begin{array}{c}\text { Total } \\
\text { Amount } \\
\text { Excreted } \\
\text { into Urine } \\
\text { (mg) }\end{array}$} & \multirow{2}{*}{$\begin{array}{c}\text { Percentage } \\
\text { of Total } \\
\text { Amount } \\
\text { Excreted } \\
(0 ;)\end{array}$} & \multicolumn{3}{|c|}{$\begin{array}{l}\text { Percentage of } \\
\text { Hourly Excretion }\end{array}$} & \multirow{2}{*}{$\begin{array}{c}\text { Total } \\
\text { Amount } \\
\text { Excreted } \\
\text { into Urine } \\
\text { (mg) }\end{array}$} & \multirow{2}{*}{$\begin{array}{c}\text { Percentage } \\
\text { of Total } \\
\text { Amount } \\
\text { Excreted } \\
\text { (ó) }\end{array}$} & \\
\hline & & & $0-4$ & $4-12$ & $12-24$ & & & \\
\hline Before PP. & 3.24 & 64.91 & 0 & 0 & $40.5 \mathrm{3}$ & 4.05 & 40.53 & 62.44 \\
\hline 1 & 3.14 & 62.85 & 0 & 14.65 & 27.67 & 4.28 & 42.32 & 67.33 \\
\hline 2 & 3.42 & 68.56 & 0 & 11.36 & 33.70 & 4.50 & 45.06 & 65.72 \\
\hline 3 & 3.47 & 69.53 & 0 & 0 & 44.77 & 4.47 & 44.77 & 64.38 \\
\hline 4 & 3.11 & 62.30 & 5.10 & 10.75 & 27.17 & 4.30 & 43.02 & 69.05 \\
\hline 5 & 3.106 & 61.27 & 0 & 0 & 41.66 & 4.16 &.+1.66 & 67.99 \\
\hline 6 & 3.40 & 68.13 & 0 & 13.88 & 81.25 & 4.51 & 45.13 & $66 . .94$ \\
\hline 7 & 3.55 & 71.09 & 0 & 18.75 & 26.59 & 4.53 & 45.34 & 63.77 \\
\hline 8 & 3.41 & 68.32 & 7.04 & 9.80 & 25.00 & 4.18 & 41.84 & 61.27 \\
\hline 9 & 3.54 & 70.83 & 0 & 0 & 44.11 & 4.41 & 44.11 & 62.27 \\
\hline 10 & 3.13 & 62.62 & 0 & 6.49 & 31.64 & 3.81 & 38.18 & 60.89 \\
\hline HP. PP. & 3.77 & 65.43 & 0 & 3.28 & 36.58 & 3.98 & 39.86 & 60.63 \\
\hline
\end{tabular}

Note: Same as Table 1

Table 8. Percentage of Intestinal Absorption in Rabbits treated with Pneumoperitoneum using Nitrogen. (Rabbit No. 7)

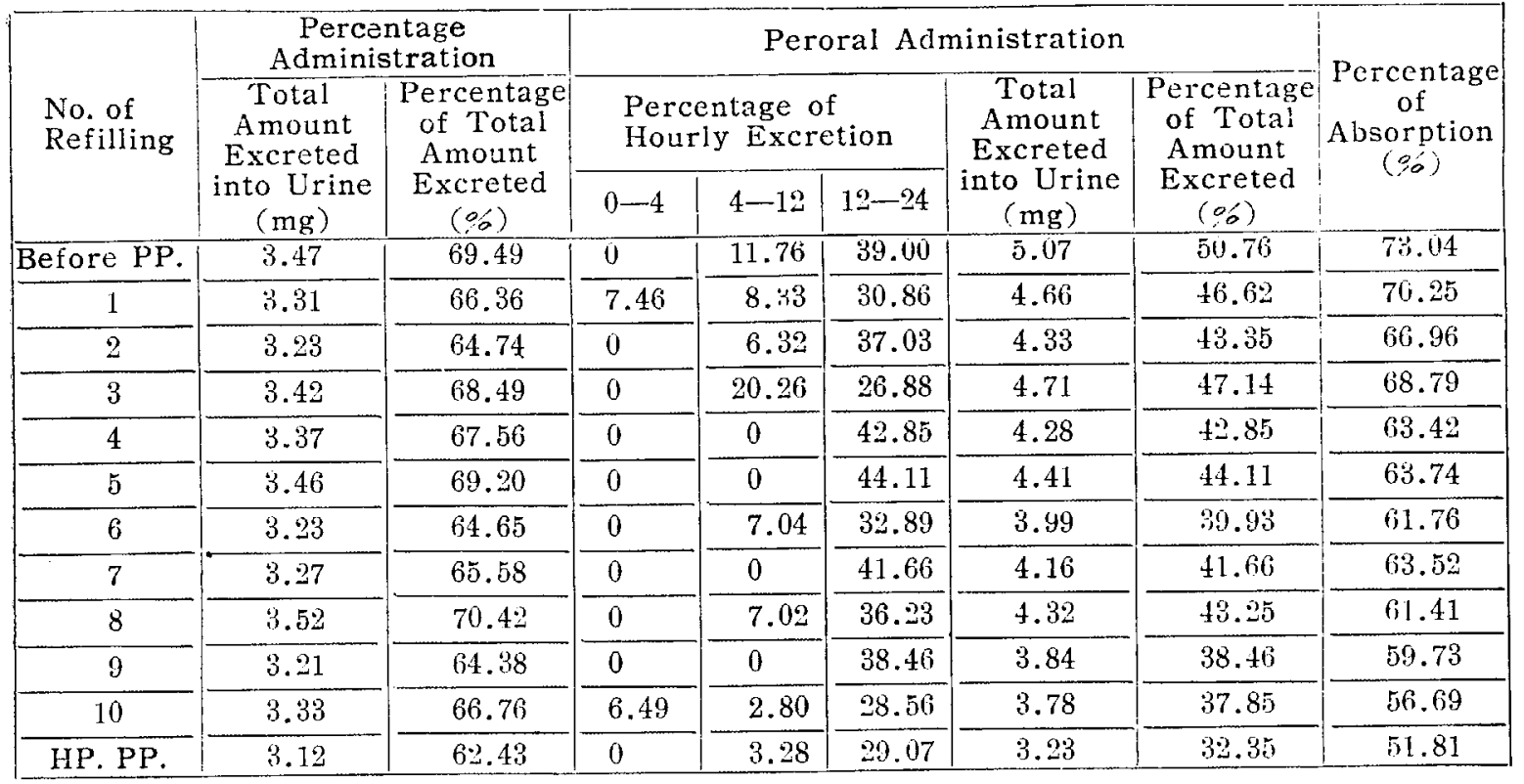

Note: Same as Table 1

を示しつ>造氮10国目には $56.77 \%$ と可成り低就 がタられた。可續いて一過性高厓载腹を行なつた 所 $57.90 \%$ となり，欧つて10四迼箫後より高い數 值を示しその影響は颜められな加つた。第6 例に
おいては氮榎前吸收率 62.41\%な゙あつたものが䢟

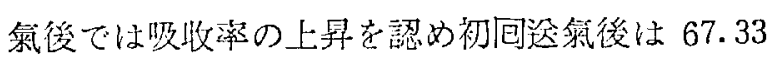

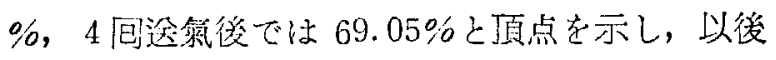
は逐次下降して8 包邆隶後では $61.27 \%$ 上氮腹前 


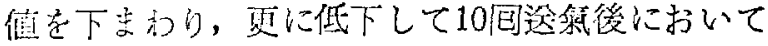
は 60.89\%となつた。しかし引續いて行なつた一

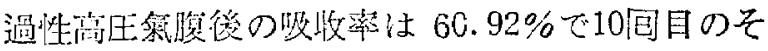
れと殆ど近似した値を示した（Table 5,6,7）。

\section{等素氮腹 :}

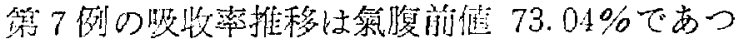

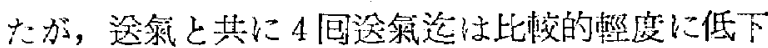
し, 以後は逐次低率となつて10回䓗州後の吸收率
は $56.69 \%$ と可成り制然たる低下が認められた。 更に一過性高圧氮腹を試みたが，二の時の吸收率 は $51.81 \%$ と著減を示した (Table 8).

II 長期常正氣腹及び离区氯腹時の晹管吸收率 次に健管家象18頭を使用し，3 種氮体による長 期管压氮腹及び医期高王氮腹を行なつた後に得ら れた吸收辩を表すると Table 9 及び Table 10 の通りであるが，今これを送人氮体别に記述しよ

Table 9. Percentage of Intestinal Absorption seen in Rabbits treated with Long Period Normopressure Pneumoperitoneum using 3 Different Gases.

\begin{tabular}{|c|c|c|c|c|c|c|c|c|c|c|c|c|}
\hline \multirow{3}{*}{$\begin{array}{c}\text { Gases } \\
\text { Inflated } \\
\text { into the } \\
\text { Peri- } \\
\text { toneal } \\
\text { Cavity }\end{array}$} & \multirow{3}{*}{$\begin{array}{l}\text { Ra. } \\
\text { bbit } \\
\text { No. }\end{array}$} & \multirow{3}{*}{$\mid \begin{array}{c}\text { Body } \\
\text { Wei- } \\
\text { ght } \\
\text { (kg) } \\
\text { and } \\
\text { Sex }\end{array}$} & \multirow{3}{*}{$\begin{array}{l}\text { Dura- } \\
\text { tion } \\
\text { of } \\
\text { PP. }\end{array}$} & \multicolumn{2}{|c|}{$\begin{array}{c}\text { Percentage } \\
\text { Administration }\end{array}$} & \multicolumn{5}{|c|}{ Peroral Administration } & \multirow{3}{*}{$\begin{array}{c}\text { Percen- } \\
\text { tage of } \\
\text { Absorp } \\
\text { tion } \\
(\%)\end{array}$} & \multirow{3}{*}{$\begin{array}{l}\text { Ave- } \\
\text { rage }\end{array}$} \\
\hline & & & & \multirow{2}{*}{\begin{tabular}{|c|} 
Total \\
Amount \\
Excreted \\
into Urine \\
$(\mathrm{mg})$
\end{tabular}} & \multirow{2}{*}{$\begin{array}{c}\text { Percen- } \\
\text { tage of } \\
\text { Total } \\
\text { Amount } \\
\text { Excreted } \\
(\%)\end{array}$} & \multicolumn{3}{|c|}{$\begin{array}{l}\text { Percentage of } \\
\text { Hourly Excretion }\end{array}$} & \multirow{2}{*}{$\begin{array}{c}\text { Total } \\
\text { Amount } \\
\text { Excreted } \\
\text { into Urine } \\
\text { (mg) }\end{array}$} & \multirow{2}{*}{$\begin{array}{l}\text { Percen- } \\
\text { tage of } \\
\text { Total } \\
\text { Amount } \\
\text { Excreted } \\
(\%)\end{array}$} & & \\
\hline & & & & & & $0-4$ & $4-12$ & $12-24$ & & & & \\
\hline \multirow{3}{*}{ Oxygen } & 10 & $2.7 \delta$ & $6 \mathrm{MI}$ & 3.56 & 71.26 & 23.14 & 0 & 23.80 & 4.69 & 46.94 & 65.87 & \multirow{3}{*}{64.01} \\
\hline & 11 & 2.39 & $6 \mathrm{M}$ & 3.28 & 65.78 & 0 & 0 & 43.10 & 4.31 & 43.10 & 65.52 & \\
\hline & 12 & 3.19 & $6 \mathrm{M}$ & 2.54 & 50.87 & 0 & 0 & 30.86 & 3.0 & 30.86 & 60.66 & \\
\hline \multirow{3}{*}{$\begin{array}{l}\text { Carbon } \\
\text { Dioxide }\end{array}$} & 13 & $\overline{2.59}$ & $6 \mathrm{M}$ & 3.78 & 75.62 & 0 & 0 & 59.52 & 50 & 52 & 78.70 & \multirow{3}{*}{68.51} \\
\hline & 14 & $\overline{2.58}$ & $6 \mathrm{M}$ & 2.92 & 58.44 & 0.43 & 17.85 & 17.64 & 3.59 & 92 & 61.46 & \\
\hline & 15 & 2.90 & $6 \mathrm{M}$ & 3.34 & 66.98 & 0 & 32.05 & 12.75 & 10 & 89 & 65.39 & \\
\hline \multirow{3}{*}{$\begin{array}{c}\text { Nitro- } \\
\text { gen }\end{array}$} & 16 & $2.4 \hat{0}$ & $\overline{6 \mathrm{M}}$ & 3.20 & 64.10 & 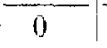 & $\overline{16.12}$ & 19.25 & 3.58 & & 55.14 & \multirow{3}{*}{50.80} \\
\hline & 17 & 2.81 & $\overline{6 \mathrm{M}}$ & 2.90 & 58.13 & 8 & 20.83 & 7.35 & 2.81 & 18 & 48.47 & \\
\hline & 18 & 2.48 & $6 \mathrm{M}$ & 3.19 & 63.82 & 0 & 0 & 31.25 & 3.12 & 31.35 & 48.96 & \\
\hline
\end{tabular}

Note: M: Months

Table 10. Percentage of Intestinal Absorption seen in Rabbits treated with Long Period Highpressure Pneumoperitoneum using 3 Different Gases.

\begin{tabular}{|c|c|c|c|c|c|c|c|c|c|c|c|c|}
\hline \multirow{3}{*}{$\begin{array}{l}\text { Gases } \\
\text { Inflated } \\
\text { into the } \\
\text { Peri- } \\
\text { toneal } \\
\text { Cavity }\end{array}$} & \multirow{3}{*}{$\begin{array}{l}\text { Ra- } \\
\text { bibit } \\
\text { No. }\end{array}$} & \multirow{3}{*}{$\begin{array}{c}\text { Body } \\
\text { Wei- } \\
\text { ght } \\
(\mathrm{kg}) \\
\text { and } \\
\text { Sex }\end{array}$} & \multirow{3}{*}{$\begin{array}{c}\text { Dura- } \\
\text { tion } \\
\text { of } \\
\text { PP. }\end{array}$} & \multicolumn{2}{|c|}{$\begin{array}{c}\text { Percentage } \\
\text { Administration }\end{array}$} & \multicolumn{5}{|c|}{ Peroral Administration } & \multirow{3}{*}{$\begin{array}{c}\text { Percen- } \\
\text { tage of } \\
\text { Absorp- } \\
\text { tion } \\
(\%)\end{array}$} & \multirow{3}{*}{$\begin{array}{l}\text { Ave- } \\
\text { rage }\end{array}$} \\
\hline & & & & \multirow{2}{*}{$\begin{array}{c}\text { Total } \\
\text { Amount } \\
\text { Excreted } \\
\text { into Urine } \\
(\mathrm{mg})\end{array}$} & \multirow{2}{*}{$\begin{array}{l}\text { Percen- } \\
\text { tage of } \\
\text { Total } \\
\text { Amount } \\
\text { Excreted } \\
(\%)\end{array}$} & \multicolumn{3}{|c|}{$\begin{array}{l}\text { Percentage of } \\
\text { Houriy Excretion }\end{array}$} & \multirow{2}{*}{$\begin{array}{c}\text { Total } \\
\text { Amount } \\
\text { Excreted } \\
\text { into Urine } \\
(\mathrm{mg})\end{array}$} & \multirow{2}{*}{$\begin{array}{c}\text { Percen- } \\
\text { tage of } \\
\text { Total } \\
\text { Amount } \\
\text { Excreted } \\
(96)\end{array}$} & & \\
\hline & & & & & & $0-4$ & $4-12$ & $12-24$ & & & & \\
\hline \multirow{3}{*}{ Oxygen } & 19 & $2.1 \quad 8$ & $6 \mathrm{M}$ & 3.34 & 66.85 & 0 & 44.64 & 1.77 & 4.0 & 46.41 & 69.42 & \multirow{3}{*}{64.84} \\
\hline & 20 & $2.4 \quad 9$ & $6 \mathrm{M}$ & 3.19 & 63 & 0 & 39.68 & 1.45 & 4. & 41 & 64.36 & \\
\hline & 21 & $2.0 \quad 9$ & $6 \mathrm{MI}$ & 3.86 & 8 & 3.96 & 30.48 & 11.36 & & 4 & 59.26 & \\
\hline \multirow{3}{*}{$\begin{array}{l}\text { Carbon } \\
\text { Dioxide }\end{array}$} & 22 & $2.6 \quad 8$ & $6 \mathrm{M}$ & 3.51 & 25 & 0 & 8.06 & 37.31 & & & 58 & \multirow{3}{*}{65.57} \\
\hline & 23 & 3.58 & $6 \mathrm{M}$ & 3.01 & 60.36 & 0 & 33.32 & 5.95 & 3.92 & 3 & 05 & \\
\hline & 24 & $2.4 \quad 3$ & $6 \mathrm{M}$ & 3.39 & 66.57 & 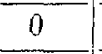 & $\overline{44.62}$ & 0.05 & 4.46 & $1,0.0$ & 67.10 & \\
\hline \multirow{3}{*}{$\begin{array}{c}\text { Nitro- } \\
\text { gen }\end{array}$} & 25 & $\begin{array}{|ll|}2.0 & 0 \\
\end{array}$ & $2 \mathrm{M}$ & 3.07 & 61.50 & 0 & 0 & 33.76 & 3.37 & 38.76 & 54.89 & \multirow{3}{*}{49.90} \\
\hline & 26 & 2.19 & $2 M$ & 3.10 & 62.03 & 0. & 0 & 27.77 & 2.77 & 27.77 & 44.76 & \\
\hline & 27 & $2.9 \%$ & $2 \mathrm{M}$ & 3.24 & 64.85 & 5.95 & 5.68 & 20.83 & 3.24 & 32.46 & 50.05 & \\
\hline
\end{tabular}

Note: M; Months 
$う$.

酸素蒾腹 :

長期常仕氮腹群の成績は 3 例中最高 $65.87 \%$, 最低 $60.66 \%$, 平均 $64.01 \%$ となり, 㕛辰期高圧 氣腹群の吸收率は最高 $69.42 \%$, 最低 $59.26 \%$, 平均 $64.34 \%$ となつて, 共に既報の對照群平均値 $70.72 \%$ に較べると稍々低率を示す結果となつた が，常圧氯腹及び高圧氣腹の數值は近似してい た。

\section{炭酸ガス氯榎 :}

長期常俚氣腹群 3 例は最高 $78.70 \%$ ，最低 61 . $46 \%$ ，平均 $68.51 \%$ の吸收率を示し，長期高圧氮 腹群では最高 $67.10 \%$,最低 $64.58 \%$,平均 65.57 $\%$ となり, 長期常圧氮腹群の平均値は對照群吸收 率に近似したが長期高任氣榎群のそれは稍 て 低率 を示した。

\section{窒素氣腹 :}

長期常圧氣腹群の吸收率は最高 $55.14 \%$, 最低 $48.47 \%$, 平均 $50.85 \%$ となり, 又, 長期高王氮 腹群のそれ注最高 $54.89 \%$ ，最低 $44.76 \%$, 平均 49. 90\%となつてそれそれ著しく低いしかも近似 した吸收率が得られた。 小括：
以上喠及の條件下における氣榎㒸鬼にみられた 吸收染につき述べたが，臨床實驗成績の項におい て試みたと同榚に上述 3 群と既報の空氮氮腹家鬼 群の吸收率につき各国每の平均值を求めて圖示す ると Fig. 2 が得られた。ます空氣氣腹時の成絟 をみると，迕氣 4〜 5 回に至るまで緩徐ながら 吸收率は上昇し，以後送氮10包に至るまで潮减し たが，引續き行なつた一過性高王氭腹時の吸收率 は 56.90\%となつて可成りの低下がみられた。. 又 酸素氣腹における短期常王氣腹時の昅收率は空氮 を用いた短期常圧氮腹時よりも更に制然と送氮回 數と共に上䊬して，送氮 6〜 7 包に至つて最高値 $81.37 \%$ となり，以後激減の傾向を示し，一過性 高王氮腹後においては可成りの低下がみられた が，しかし氮腹前值を下まわる值にはならなかつ た。これら兩群に比較すると，孷酸ガス氣腹群と 窒素氣腹群とは可成り類似の傾向を示し，迼氣回 數の重なると共に吸收率は低下したが，空素氣腹 群における低下の傾向法特に顯著であつた。次に 常圧氮腹及び高王氣腹を長期間實施した後にお汀 る吸收率の平均值を表示するとTable 11の如くな つた，節方各群共しかも常区氣腹群に較べ高圧氯 腹群の方が對照群平均值 $70.72 \%$ に較べると大な

Fig. 2. Fluctuation of Mean Values of Intestinal Absorption Percentage seen in Rabbits treated with Pneumoperitoneum using 4 Different Gases.

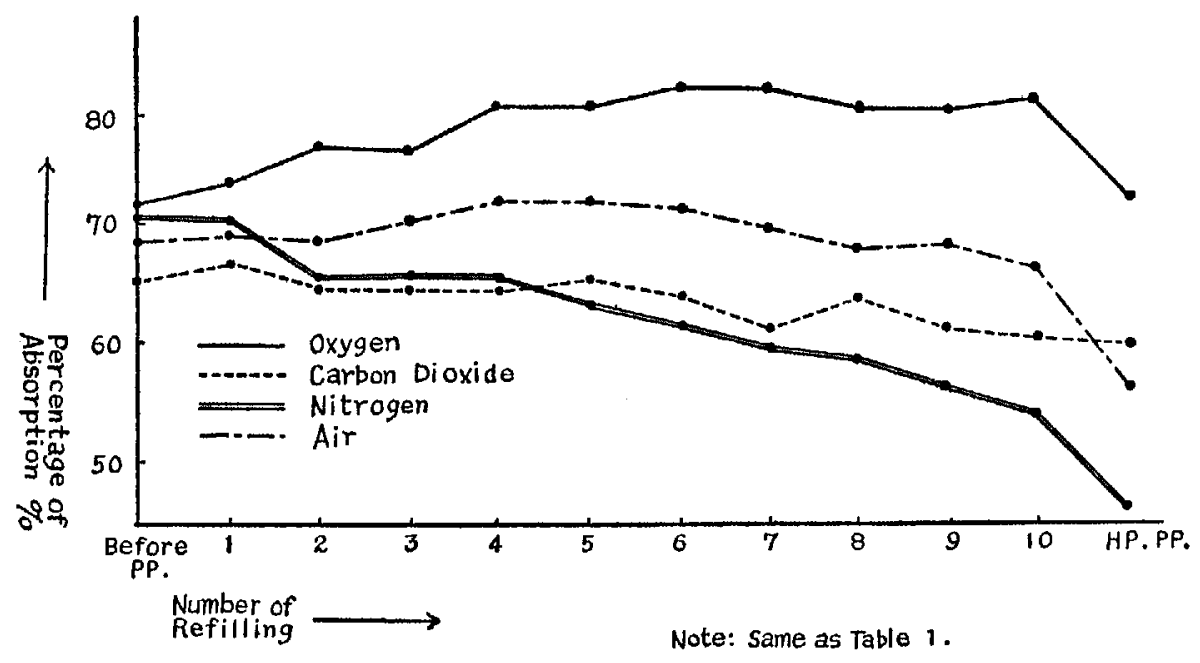


Table 11. Mean Values of Intestinal Absorption Percentage seen in Rabbits treated with Long Period Normo-and High-Pressure Pneumoperitoneum.

\begin{tabular}{|c|c|c|}
$\begin{array}{c}\text { Gases inflated } \\
\text { into the } \\
\text { Peritoneal } \\
\text { Cavity }\end{array}$ & $\begin{array}{c}\text { Intra- } \\
\text { abdominal } \\
\text { Pressure }\end{array}$ & $\begin{array}{c}\text { Percentage of } \\
\text { Absorption } \\
(\%)\end{array}$ \\
\hline Air & NP.PP. & 68.97 \\
\hline HP.PP. & 56.77 \\
\hline Oxygen & NP.PP. & 64.01 \\
\hline $\begin{array}{c}\text { Carbon } \\
\text { Dioxide }\end{array}$ & NP.PP. & 64.34 \\
\hline Nitrogen & NP. PP. & 68.51 \\
\hline Controls & HP. PP. & 65.57 \\
\hline Note: & 50.85 \\
\hline NP. PP.: & $\begin{array}{l}\text { Normopressure } \\
\text { Pneumoperitoneum } \\
\text { Highpressure } \\
\text { HP. PP.: }\end{array}$ \\
\hline
\end{tabular}

り小なり低下しており，特に窒素氣腹群において は常圧氮腹時，高圧氮腹時共に低下が著明であつ た。

\section{總括及び考按}

以上臨床的立びに實驗的に酸素, 孷酸ガス及び 窒索の 3 種涾体を用いて實施した氮腹時の吸收率 について記迅し，しかも既報の空氮氮腹時におけ る成績を併記して小括を試みておいたが，更にこ れを總括し $2 ， 3$ の教祭をめぐらしたい。

短期間の常压氣腹時及びこれに引續いて實施し た一過性高仕氣腹時の吸收率の推移をみると，臨 床實驗においても動物實驗においても頗る類似の 成續が得られた。師ち空氧伎び酸素を用いた場合 に核氮一定回數までは吸收率の上㫧が確認され たのに對し，炭酸分ス殊に等素を用いた場合には 吸收率の上昇は全く認められずして远氮回數と共 に漸減していつた。而して一過性高王氣腹を設置 すると空氯及び筀素使用群では吸收率が著明に低 下した。次に家秉に長期間の常圧氮腹及び高玨氮 腹を惯施してその吸收率を求めた所，各乘体群共 氯胹實施前平均値に較べると低下を示したが，そ
の低下の度は窒素氣腹群で特に㙷著であり, 又韦 期常圧氮腹と長期高圧氮腹とを比較すると各群共 後者の方が低値であつた。

かくの如く䢪大氣体の異なるにより，又同一氮 体でも邆入方法の異なるによつて吸收率の差が認 められた事汢誠に興味ある事實と言わざるを得な い. 㸚宝においてはすでに常压氮腹と高王氣腹實 施時における諾器官の機能が 2,3 の方面より追 求されている。例えば敎室碓井4)は，氣腹の肝藏 機能に期える影辝を精查した結果，常压氣腹時に おけるよりも高王氣腹時における方分高度の障害 㚙認められる事， 又同じく常王氣腹でも酸素殊 に炭酸ガスよりも空兆殊に空素を用いた方が障書 がひぞい事，しかもこれ等障害の．主原因は扞䓵 の殹血に起因するものであろう事等を報告してい る. 倘又南5)677) は攻腹時腎臟機能を精查し, 又宮

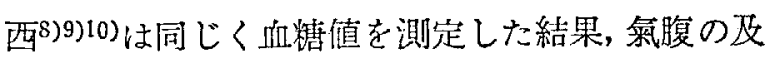
汪す影響の假向としては歸を一にする成績を得て いる. 此等諸成績は一軈腹圧の高低という問題を 介して說明出來る所であり，又邆入氮体の異なる によつて買なつた結果の得られた事も，教室岩 本11の成績師ち腹腔内に䢒入された窒素, 空氮, 酸 素, 宸酸ガスの吸收される時間的速度をみると空 氣殊に窒素は酸素殊に炭酸ガスよりも遲延される 事よりして，結局 4 種氣体法その生物學的或は化 學的な直接作用を諸醎器に與えるために惹起され たものではなくて，吸收の嘱速によつて生じた腹 貯内王高低の差という問題を介七て起きた障害で あろうと說明し得るであうう。所が絠言において 既に一言した如く教宝井村等の成續によると, 細 網内皮系幾能は腹腔内に空氣殊に酸素を䢪入した 場合には克進するのに對し，炭酸ガ久殊に窒素を 途入した際には低下する事が認められている。こ の成績に併せて上述の如く酸素及び空氮を用いた 常圧氮腹の初期に吸收率の上昇方認められた事は 誠に眮味ある所であるが，如何なる機轉によつて か〉る一連の現象が㧍きたかの說明は更に辐驗を 進めた上で考察したい。

\section{結語}




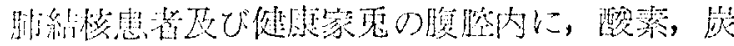

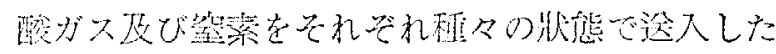

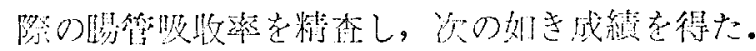

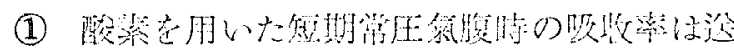

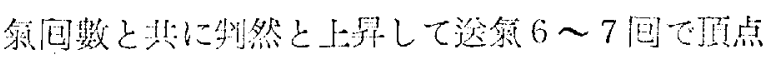

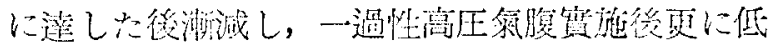

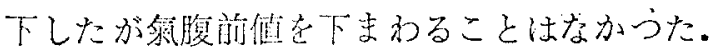

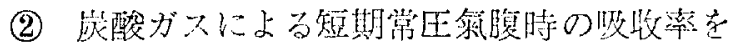

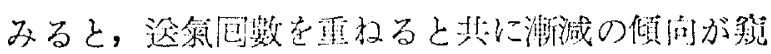
われた。

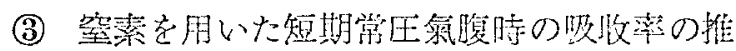

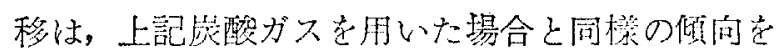
示したが，その程度は更に頶薪であつた。

(4) 長期間にわたつて實施した常圧籍腹及び高 压氯腹後の吸收率は，いずれの碓においても氮腹

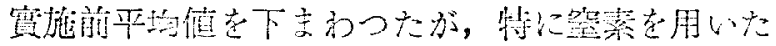
場合に注影篦であつた。

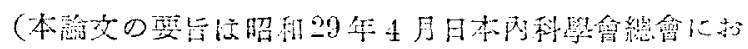
いて器琵した).

\section{文 献}

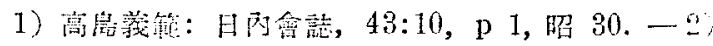

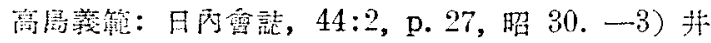

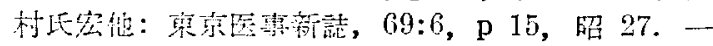

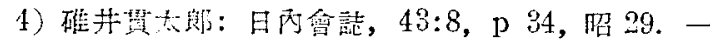

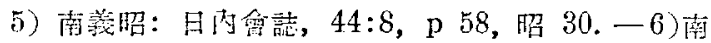

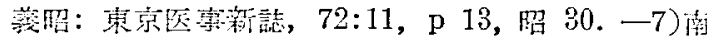

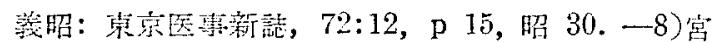

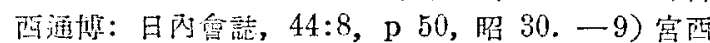

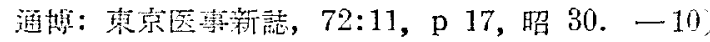

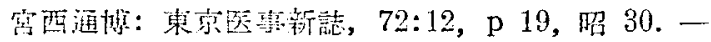
11)品本利堆：結核，29:7， p 31。昭 29 .

[受稿・眧利31年2月14日] 